\title{
Environmental Economic Security Management of a Coal Mining Enterprise
}

\author{
Vladimir Mikhailov ${ }^{1},{ }^{*}$ Alexander Pimonov ${ }^{2,3}$, Yana Mikhailova ${ }^{1}$, Anna Barbara $^{4}$, and Juraj \\ Janocko $^{5}$ \\ ${ }^{1}$ T.F. Gorbachev Kuzbass State Technical University, Department of Production Management, 650000 \\ Kemerovo, 28 Vesennya st., Russian Federation \\ ${ }^{2}$ T.F. Gorbachev Kuzbass State Technical University, Department of Applied Information \\ Technologies, 650000 Kemerovo, 28 Vesennya st., Russian Federation \\ ${ }^{3}$ Institute of Economics and Industrial Engineering of the Siberian Branch of the Russian Academy of \\ Sciences, 630090 Novosibirsk, 17 Acad. Lavrentyev Av., Russian Federation \\ ${ }^{4}$ T.F. Gorbachev Kuzbass State Technical University, Mezhdurechensk Branch, 652881 \\ Mezhdurechensk, 36 Stroiteley st., Russian Federation \\ ${ }^{5}$ Technical University Košice, Faculty BERG, Letná 9, 04001 Košice, Slovakia
}

\begin{abstract}
The structure of the mining environmental economic system, where the key role is played by a coal mining enterprise or a set of enterprises, combined, among other things, with a coal-processing infrastructure, is studied in the article. Known approaches to the definition and the features of assessing the regional environmental economic security of a coal mining enterprise are analyzed. The structure of environmental economic security management of an industrial enterprise operating in an industrialized region is considered and a method for achieving the required level of environmental economic security, expressed in the form of a cost estimate of this process, is proposed. The work performed is of practical importance for environmental surveillance of various levels and large industrial enterprises, especially those related to coal mining and processing, in order to predict the required level of environmental economic security.
\end{abstract}

\section{Introduction}

It is advisable to study the processes of ensuring environmental economic safety for a region with an overdeveloped coal mining industry, such as Kuzbass, in terms of the mining environmental economic system. Not only the entire Kemerovo region, but also the local environmental economic system "coal mining (coal processing) enterprise - environment" [1] can be considered such a system (Fig. 1).

The peculiarity of the mining environmental economic system is considering a coal mining enterprise as a separate block, which in a decisive way affects both the economic stability of a region and the state of environment.

Ensuring environmental economic safety for a region and its local components depends on the specifics of economic development, where the basic industries play a key role [2].

\footnotetext{
* Corresponding author: mvg.eohp@,kuzstu.ru
} 


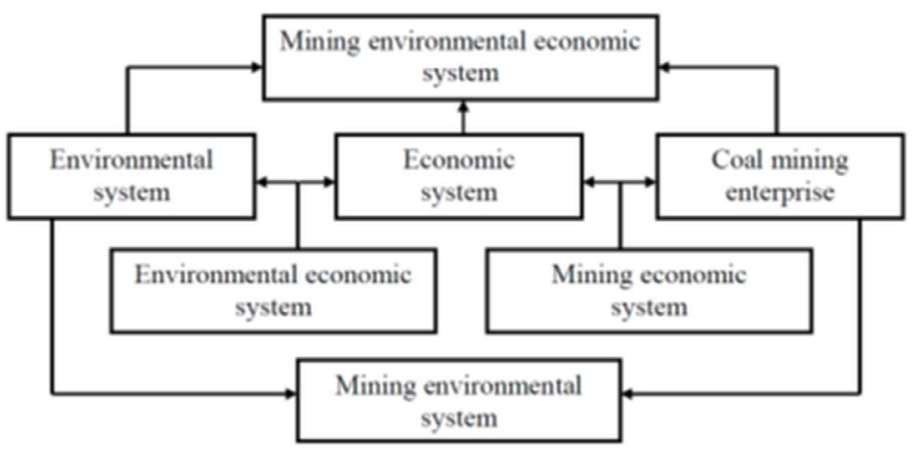

Fig. 1. Simplified diagram of the mining environmental economic system.

In modern conditions, environmental economic security of a region or a constituent entity of the Federation can be defined as a set of the current state, conditions and factors that characterize the sustainability of the economic development of the territory, stability, efficiency in the use of natural resources and the production and economic potential of a region or a constituent entity in order to raise the standard of living of the population [3 - 6].

The efficiency of environmental economic security management at all levels depends on many factors, among which the most important is the specifics of facilities that have a negative impact on the environment, the territorial distribution of enterprises taking into account the natural and urban environmental component, the whole range of laws, orders, standards and requirements aimed at improving the environmental situations, and the presence of close and rational interaction between all environmental management structures, enterprises of the real economy, and other participants of the system. Decisions made by the world community, individual states and territorial entities show that environmental economic security at the present stage of development of society is becoming not only the most important condition for economic activity, but also the determining principle of the economic mechanism for meeting the needs of all regions [3].

\section{Materials and methods}

The object of the research is environmental economic security of the region with an increased anthropogenic load. The subject of the research is the structural features of ensuring the regional environmental economic security and the ways to achieve its required level. The study is based on the analysis of Russian literary sources on the problems of ensuring environmental economic security. Particular attention is paid to the way to achieve a given level of the environmental economic security based on the building of oriented graphs. The work used the elements of systems analysis and the results obtained by specialists in the field of environmental economic security.

\section{Results and discussion}

Many publications of Russian and foreign scientists are devoted to the study of the problem of ensuring environmental economic security. The work [7] describes the place of environmental economic security in the overall system of global, regional and local economic safety. N.E. Buletova defines environmental economic security as a set of states, processes and actions that can ensure a balance of interests of the national (regional, local) economy 
and environment that do not lead to violations (or threats of such violations) of the natural environment and society according to the standards established by legislation. In this work, a structure for monitoring environmental economic security of the regions of the Russian Federation has been developed, including monitoring the quality of life, environmental and economic state and public finances [8]. Another definition of environmental economic security is presented in [9]: the state of protection of the vital interests of a person, society, and the natural environment of the region from threats caused by the impact of the life of people and economic sectors on the natural environment and, in turn, of the natural environment on people and business entities. N.N. Skiter formulated the following levels of environmental economic security: family and personal; microeconomic; regional; macroeconomic; megaeconomic.

The same study presents environmental economic security indicators - quantitative values of the state of the social ecosystem that determine the degree of its protection from external and internal threats, and threshold values - the limit values of safety indicators and criteria, exceeding or decreasing which leads to the emergence and spread of negative, destructive processes in the social ecosystem [3]. In the considered work [7], an important conclusion was made that environmental economic security of enterprises is influenced by the costs of environmental protection, and the difficulties in predicting and preventing objective threats to environmental economic security are complicated by the synergistic effect of various factors with a huge number of their combinatorial variations. One of the options for assessing environmental economic security and risks of enterprises is presented based on the use of the mathematical tools [10 - 12] of fuzzy logic. In addition, the zoning of threats to environmental economic security was carried out and a method was developed for assessing the efficiency of recommendations on a set of necessary measures to prevent damage and minimize losses [13].

There are many other studies devoted to this problem [14 - 18].

The organizational structure of environmental economic security management of an enterprise includes three levels [17]:

- territorial management body;

- low-level enterprise management;

- top- and middle-level enterprise management.

The territorial management body determines the requirements for environmental economic security management systems at enterprises and control over their implementation. Such requirements are the provision of enterprises with all the necessary approval documents (Admissible Exposure Standards, Allowable Discharge Standards, limits on waste disposal, sanitary protection zones, transition to the principles of the best available technologies, etc.) and other elements.

Low-level enterprise management implements the environmental economic security requirements in specific production shops, sites and industries, in relation to existing processes and equipment.

Middle-level (departments of environmental protection, process control and quality management systems) adapt the requirements for ensuring environmental economic security to the departments of an enterprise (sections, workshops, production units).

Top-level enterprise management (Board of Directors, General Director, Chief Technology Officer or Chief Engineer) develop strategic or tactical (annual) environmental management plans depending on the departmental requirements.

The environmental economic security level is interpreted as a complex or integral indicator characterizing the environmental economic security management system used at the enterprise. The environmental economic security level is determined on the basis of the probability of operation of an enterprise without generating environmental accidents (bulk emissions and discharges of pollutants, significant excess of production and consumption 
waste generation limits, and others). Another variant is the expected economic damage from environmental accidents at enterprises that use the principles of BAT and are the best according to the environmental economic security criterion in relation to the expected economic damage at this enterprise.

The environmental economic security level is standardized by various methods depending on the characteristics of an enterprise:

- industry;

- characteristics of the negative impact on the environment;

- use of BAT principles;

- certification according to ISO 14001-2015 standards;

- process hazard class;

- actual level of environmental economic security;

- others.

Due to the fact that an enterprise cannot make a quick transition from low environmental economic security level to the corresponding international standards, for example, BAT, it is required to establish intermediate values of environmental economic security within a certain period of time, which are set by the control center.

The control center ensures the gradual transition of enterprises to a given level of environmental economic security, determining the values of the required indicators for each period

It is advisable to consider the choice of a strategy for increasing the environmental economic security level in two successive stages. The first stage includes the development of a strategy for increasing the regional level of environmental economic security.

At the second stage of choosing a strategy for increasing the regional environmental economic security level, the standard environmental economic security level of each enterprise is determined.

Information on the costs of achieving environmental economic security values should be provided by enterprises as an element of reporting on the state of environmental economic security management system at the enterprise. An important problem of ensuring control over environmental economic security management system is the reliability of the reporting data of enterprises-users of natural resources. Such reliability should be ensured on the basis of the control mechanism of environmental economic security management system at the enterprise, which in many respects corresponds to the current organizational and economic mechanism for environmental management, which includes the following elements:

- fines;

- prescriptions;

- closure of enterprises;

- increase in tax deductions;

- pollution fees and others.

As a result, it is possible to formulate the main tasks, the solution of which will increase the regional level of environmental economic safety:

- determination of a strategy for increasing the regional level of environmental economic security;

- search for standard environmental economic security levels for the enterprises-users of natural resources located in the region;

- selection of a system of sanctions motivating enterprises to provide reliable information about the state of environmental economic security management system.

The efficiency of one of the approaches using oriented graphs can be estimated using the cost of each type or stage of work required to achieve the required final value. One conventional unit of the resource was taken in the amount of 100 million rubles. The choice of the most effective scenario includes the condition that the time required for the 
achievement along a specific path is insignificant. In such conditions, the criterion of efficiency is the minimum required costs.

An example of testing the use of oriented graphs on a basis of certain types of work in terms of minimizing the resources used, expressed in costs, is shown in Table 1.

Table 1. An example of testing the use of oriented graphs to achieve a given level of environmental economic security.

\begin{tabular}{|c|c|c|c|}
\hline $\begin{array}{c}\text { Scenario of achieving the final level of } \\
\text { environmental economic safety }\end{array}$ & $\mathbf{1}$ & $\mathbf{2}$ & $\mathbf{3}$ \\
\cline { 1 - 2 } Types of work and their cost estimate, million rubles & 5250 & 3150 & 2800 \\
\hline $\begin{array}{c}\text { Modernization of industrial processes based on BAT } \\
\text { principles }\end{array}$ & 375 & 225 & 200 \\
\hline $\begin{array}{c}\text { Certification of industrial processes according to } \\
\text { standards ISO-14001 } \\
\text { Improvement of the organizational structure of }\end{array}$ & 750 & 450 & 400 \\
\hline $\begin{array}{c}\text { Improvement of regional environmental legislation } \\
\text { Other types of work }\end{array}$ & 375 & 225 & 200 \\
\hline Total & 750 & 450 & 400 \\
\hline
\end{tabular}

Table 1 shows that the most "resource-intensive" stage or type of work is the process modernization of on the principles of BAT. At the same time, the achievement of the final environmental economic security level for 3 periods requires a minimum amount of resources (4 billion rubles), which is significantly lower than the use of two (4.5 billion rubles) or one ( 7.5 billion rubles) periods. The values of the cost of certain types of work were obtained on the basis of actual data of the largest enterprises of the Kemerovo region - Kuzbass and with the help of expert estimates.

The study of such a system was carried out using a number of environmental economic indicators, where the central place is occupied by economic damage from environmental pollution - economic losses of an enterprise caused by negative environmental impact [19, 20]. When studying this indicator, determining the weighted average hazard class of pollutants and production and consumption wastes is of great importance, which makes it possible to identify the most significant groups of negative impact on the environment (Table 2).

The results presented in Table 2 show a clear trend, according to which "risk groups" for individual elements of the environment have been identified:

- for emissions of pollutants into the air - ingredients of the 2nd hazard class

- for discharges of pollutants with wastewater - ingredients of the 3rd hazard class;

- for the disposal of production and consumption waste - 5th hazard class. 
Table 2. The results of determining the weighted average hazard class for the main elements of the negative impact on the environment by the JSC "SUEK-Kuzbass" S.M. Kirov mine.

\begin{tabular}{|c|c|c|c|c|c|}
\hline $\begin{array}{c}\text { Element of negative impact on the } \\
\text { environment }\end{array}$ & $\mathbf{2 0 1 3}$ & $\mathbf{2 0 1 4}$ & $\mathbf{2 0 1 5}$ & $\mathbf{2 0 1 6}$ & $\mathbf{2 0 1 7}$ \\
\hline Emissions of pollutants into the air & II & II & II & II & II \\
\hline $\begin{array}{c}\text { Discharge of pollutants with } \\
\text { wastewater }\end{array}$ & IV & III & III & III & III \\
\hline $\begin{array}{c}\text { Disposal of production and } \\
\text { consumption waste }\end{array}$ & V & V & V & V & V \\
\hline
\end{tabular}

\section{Conclusion}

The conducted research, which is of practical importance in planning effective environmental protection activities, allows drawing the following conclusions:

- the known approaches to the definition, structure and features of environmental economic security assessment for entities of different levels are analyzed;

- a three-level organizational structure for environmental economic safety management of a coal mining enterprise is designed;

- various approaches to assess the regional level of environmental economic security are considered;

- an example of designing possible strategies based on an oriented graph with the determination of the costs required to achieve a given level of environmental economic security is given;

- the weighted average hazard class of pollutants and production and consumption wastes is determined to identify environmental bottlenecks and develop measures to ensure environmental economic security.

\section{References}

1. V.G. Mikhailov, S.M. Bugrova, Ju.S. Yakunina, A.K. Muromtseva, Ya.S. Mikhailova Ugol, 9 106-111 (2019)

2. V. Baranov, N. Makhutov, Management of large-scale system development (MLSD, Moscow, 2019)

3. N.N. Skiter, A.F. Rogachev, T.I. Mazaeva, Mediterranean Journal of Social Sciences, 36(6), 185-192 (2015)

4. V.M. Zolotukhin, V.A. Gogolin, M.Yu. Yazevich, M.I. Baumgarten, A.V. Dyagileva IOP Conf. Series: Earth and Env. Sci. 50, 012027 (2017)

5. V.M. Tumin, A.G. Koryakov, E.P. Nikiforova, World Applied Sciences Journal, 25(6), 945-949 (2013)

6. V.M. Tumin and A.G. Koryakov, Middle East Journal of Scientific Research, 17(9), 1350-1355 (2013)

7. A.V. Veretyokhin, V.M. Yachmeneva, O.V. Sevastyanova, Z.O. Osmanova, E.F. Yachmenev, International Journal on Emerging Technologies, 11(2), 192-197 (2020)

8. N.Ye. Buletova, I.V. Gorelova, A.V. Golomanchuk, Ye.R. Orlova, Economy of Region, 42(2), 59-71 (2015) 
9. A. Salamatov, D. Gordeeva, A. Agapov WIT Transactoins on Ecology and the Environment, 245(2), 157-164 (2018)

10. V.P. Avdeev, V.N. Burkov, T.V. Kiseleva, Automation and Remote Control, 62(10), 1645-1650 (2001)

11. I.A. Ageev, V.N. Burkov, V.I. Zinchenko, T.V. Kiseleva, Automation and Remote Control, 66(6), 995-1002 (2005)

12. P. Kosinskiy, V. Merkuriev and A. Medvedev, E3S Web of Conf. 134, 03009 (2019)

13. A.F. Rogachev, V.N. Ostrovskaya, A.S. Natsubidze, T.N. Litvinova E.A. Yakovleva, Advances in Intelligent Systems and Computing, 622, 241-247 (2018)

14. S.A. Barkalov, A.I. Polovinkina, 15-th Int. Conf. on Systems Science (Wroclaw University of Technology, Wroclaw, 2004)

15. P.V. Druzhinin, G.T. Shkiperova, Studies on Russian Economic Development, 23(1), 66-72 (2012).

16. A.V. Novichikhin, V.N. Fryanov, T.V. Petrova, L.D. Pavlova, M.V. Temlyantsev, IOP Conf. Series: Earth and Env. Sci. 84, 012036 (2017)

17. T.V. Kiseleva, V.G. Mikhailov Ya.S. Mikhailova, Economics and Innovation Management, 1 63-73 (2021). DOI: 10.26730/2587-5574-2021-1-63-73

18. V.G. Mikhailov, T.V. Galanina, Ya.S. Mikhailova, Gornyi Zhurnal, 4, 89-93 (2019)

19. Y.V. Ryumina, Economy of Region Issues, 12(4), 1113-1122 (2016)

20. T.Y. Anopchenko, O.I. Gorbaneva, E.I. Lazareva, A.D. Murzin, G.A. Ougolnitsky, Advances in systems science and applications, 18(4), 136-150 (2018) 